\title{
AN ANALYSIS OF THE MECHANISMS IN NEW ZEALAND \\ LAW TO PROTECT EMPLOYEE ENTITLEMENTS IN THE EVENT OF EMPLOYER INSOLVENCY AND THEIR EFFECTIVENESS
}

\author{
Trish Keeper*
}

\begin{abstract}
In New Zealand, scarcely a week goes by without news of workers who, due to the insolvency of their employer, have lost their jobs and are owed sometimes thousands of dollars for unpaid wages, holiday pay, redundancy payments or other bonuses. The focus of this article is the mechanisms that exist in New Zealand law to ensure that such workers receive these unpaid entitlements and the effectiveness of such mechanisms. The principal mechanisms discussed are the treatment of unpaid employee entitlements as a preferential claim in the liquidation of an insolvent company and the general powers in the Companies Act 1993 (NZ), which are generally exercised by liquidators, to bring personal actions against directors and others for misconduct on behalf of the creditors generally. The article concludes that New Zealand workers are less protected than their counterparts in comparative jurisdictions, but argues that any solution is unlikely to be found in insolvency law.
\end{abstract}

\footnotetext{
* Associate Professor in Commercial Law, Wellington School of Business and Government, Victoria University of Wellington.
} 


\section{INTRODUCTION}

\section{A Background and Overview of Article}

In New Zealand, scarcely a week goes by without news of workers who, due to the insolvency of their employer, have lost their jobs and are owed sometimes thousands of dollars for unpaid wages, holiday pay, redundancy payments or other bonuses. The focus of this article is the mechanisms that exist in New Zealand law to ensure that such workers receive any unpaid entitlements and the effectiveness of such mechanisms. It is common in cases of business failure for unsecured creditors to not receive all amounts owed to them, and the impact of nonpayment on employees is particularly hard. Employer insolvency can not only create financial hardship for employees, but result in 'significant psychological and other effects from the stress of no income, and create ripple effects in the economy and the local community in which the insolvent corporation was located'. ${ }^{1}$

The first part of the article outlines the rationale for prioritising the payment of unpaid amounts owed to workers and how these objectives have been recognised in various international guides and conventions. It then outlines the preference mechanism in New Zealand corporate law, and this analysis concludes by explaining how preference regimes have been improved in other countries by the addition of institutional guarantees and subrogation arrangements. There are a range of other provisions in the Companies Act 1993 (NZ) ('Companies Act') that may potentially impose liability on those in charge of companies who have acted improperly in relation to the failure of the company, although there are no provisions directly focused on exposing directors to personal liability for unpaid employee entitlement. The article outlines these provisions and how they are enforced. Although, as the article suggests, the low level of enforcement actions against directors and others in charge of companies mitigates such liability provisions achieving their objectives of deterrence of directorial misconduct and inattention to a company's affairs. ${ }^{2}$ Finally, the article concludes by discussing the need for reform, and suggests that any improvements will need to be driven by the labour movement, rather than relying on insolvency law.

\section{B Context}

The article focuses on employees of insolvent companies that are in liquidation, although it is recognised that unincorporated businesses, such as partnerships and sole traders, also may have workers who have unpaid entitlements on the insolvency of their employer. ${ }^{3}$ This focus on companies is for the sake of simplicity and also because limited liability companies are the

\footnotetext{
1 Janis Sarra, 'Widening the Insolvency Lens: The Treatment of Employee Claims' in Paul J Omar (ed), International Insolvency Law, Themes and Perspectives (Ashgate Publishing, 2008) 295, 295.

2 Helen Anderson, 'Corporate Insolvency and the Protection of Lost Employee Entitlements: Issues of Enforcement' (2013) 26 Australian Journal of Labour Law 75, 75-76.

${ }^{3}$ Insolvency Act 2006 (NZ) ss 274-76 sets out a preferential payment regime, which largely replicates that found in the Companies Act 1993 (NZ) ('Companies Act') under which certain unpaid employee entitlements are paid as a second-ranking claim pursuant to $\mathrm{s} 274(2)$.
} 
most common form of business structure in New Zealand. Any company incorporated under the Companies Act has a separate legal identity from its shareholders and its directors. ${ }^{4}$

Finally, as stated, this article focuses on insolvent corporate employers who are placed in liquidation, either voluntarily by a resolution of the shareholders or by the court. ${ }^{5}$ It does not discuss companies that are placed in receivership or voluntary administration. However, receivers to the extent that they are appointed under a security agreement that covers accounts receivable and inventory of the company in receivership are subject to a requirement to pay out the proceeds from the realisation of such assets in accordance with the preferential claims regime that governs payments by a liquidator as set out in sch 7 of the Companies Act. ${ }^{6}$

In terms of voluntary administration, employees who are owed unpaid emoluments have no special rights to payment, but as creditors of the company they have a right to vote at any meeting of creditors, including the watershed meeting that decides the ultimate fate of the company. ${ }^{7}$ Although employee contracts are not automatically terminated on the appointment of a voluntary administrator, the administrator may give notice of the termination within 14 days of appointment. ${ }^{8}$ In practice, often employees are paid out in full, together with other smaller creditors, leaving creditors who are owed larger amounts to be part of the compromise negotiations, which ultimately result in a deed of company arrangement if the company continues into administration.

\section{RATIONALE AND OPTIONS FOR THE SPECIAL TREATMENT OF EMPLOYEES AS CREDITORS}

\section{A Rationale}

When a business fails, often there will be a substantial amount owed to the employees of that business. However, employees as creditors of that business possess unique characteristics that distinguish them from other creditors. First, they will usually lose their primary or sole source of income (their job) as well as being owed money for previous services. Second, they generally fail to perceive the risk that they may not be paid until the employer is suffering significant financial distress or they lack the power to mitigate the risk of non-payment. Other unsecured creditors, at least in theory, are able to incorporate some premium into the amount they charge for goods and services supplied to the business in order to counterbalance the risk of nonpayment. This is rarely possible for wage earners. ${ }^{9}$ Also, employees are unique in that, unlike

\footnotetext{
${ }^{4}$ Companies Act s 15.

${ }^{5}$ Ibid s 241(2)(a)(b).

${ }^{6}$ Receivership Act 1993 (NZ) s 30.

${ }^{7}$ Companies Act ss 239AN, 239ABA.

${ }^{8}$ Ibid ss $239 \mathrm{Y}(1), 239 \mathrm{Y}(3)$. The administrator becomes personally liable for the wages and salary of any employee whose employment is not terminated, and this therefore becomes a cost of the administration, which is paid as part of the first-ranked priority claims in the event the company ends in liquidation, under Companies Act sch 7 cl 1(1)(b).

9 Susan J Cantlie, 'Preferred Priority in Bankruptcy' in Jacob S Ziegel and Susan J Cantlie (eds), Current Developments in International and Comparative Corporate Insolvency Law (Oxford University Press, 1994) 423.
} 
most other creditors, they are usually dependent on a single source of income and are unable to reduce the risk of non-payment by one employer by entering into multi-employment contracts with other businesses. Another argument that has been put forward is that, 'as employees do not normally share in the profits of the enterprise, they should not share in its losses either'. ${ }^{10}$ Furthermore, employees have conferred value on the company through their labour and loyalty - a contribution of 'time, energy and creativity over and above the current wage/labour exchange'. ${ }^{11}$

\section{B International Principles}

Many countries have recognised the need to enact some form of employee wage protection mechanism, which in the advent of employer insolvency acts to ensure that employees receive some, or all, of any unpaid wages and other related claims. However, there is no uniform approach to the form of this recognition, in practice, and there is also little uniformity among international institutions as to the best approach to be taken.

For example, the World Bank's Principles and Guidelines for Effective Insolvency and Creditor Rights Systems states:12 "Workers are a vital part of an enterprise, and careful consideration should be given to balancing the rights of employees with those of other creditors. ${ }^{13}$ However, the Principles and Guidelines more generally observe that

proceeds available for distribution should be distributed pari passu to the remaining general unsecured creditors, unless there are compelling reasons to justify giving priority status to a particular class of claims. Public interests generally should not be given precedence over private rights. ${ }^{14}$

Similarly, the United Nations Commission of International Trade Law ('UNCITRAL') in its 2005 Legislative Guide on Insolvency Law also observed that there is a need to construct priority regimes narrowly, but that most nations have adopted measures to ensure the special treatment of employees. The Guide notes that

insolvency laws often attribute priority rights to certain (mainly unsecured) claims, which in consequence will be paid in priority to other, unsecured and non-privileged (or less privileged) claims. These priority rights, which are often based upon social, and sometimes political, considerations, militate against the

${ }^{10}$ General Survey of the Reports Concerning the Protection of Wages Convention (No. 95) and the Protection of Wages Recommendation (No. 85), 1949: Report of the Committee of Experts on the Application of Conventions and Recommendations (Articles 19, 22 and 35 of the Constitution), International Labour Organization ('ILO') Report III (Part 1B), International Labour Conference, $91^{\text {st }}$ sess (2003) [299].

11 Sarra (n 1) 297.

${ }^{12}$ The World Bank's Principles for Effective Insolvency and Creditor/Debtor Regimes were originally developed in 2001 in response to a request from the international community in the wake of the financial crisis of the late 1990s. The Principles were revised in 2005, 2011 and 2015. See World Bank, Principles for Effective Insolvency and Creditor/Debtor Regimes (World Bank Publications, 2016) $<$ http://pubdocs.worldbank.org/en/919511468425523509/ICR-Principles-Insolvency-Creditor-Debtor-Regimes2016.pdf $>$.

${ }^{13}$ Ibid 25, Principle C12.4.

14 Ibid 25, Principle C12.3. 
principle of pari passu distribution and generally operate to the detriment of ordinary unsecured creditors by reducing the value of the assets available for distribution to them. ${ }^{15}$

In terms of payments to employees, the Guide notes that

\begin{abstract}
in a majority of States, workers' claims (including claims for wages, leave or holiday pay, allowances for other paid absence and severance pay) constitute a class of priority claims in insolvency. ... The approach of providing priority for workers' claims is generally consistent with the special protection that is afforded to employees in other areas of insolvency law ... as well as with the approach of international treaties on protection of workers. ${ }^{16}$
\end{abstract}

The International Labour Organization's ('ILO') approach is more pro-worker than that of the World Bank and UNCITRAL. The ILO in 1949 adopted the Protection of Wages Convention ('C 95'). ${ }^{17}$ Article 11 of $\mathrm{C} 95$ provides that workers' wages due for services provided during a certain period prior to the liquidation or up to a certain amount should be treated as a privileged debt, although details of the nature of that privilege are left to the discretion of the ratifying nations. In addition, the Protection of Workers' Claims (Employer's Insolvency) Convention ('C 173'), which was adopted by the ILO in 1992, has the objective to strengthen the protection afforded to workers' claims by requiring ratifying countries to either protect workers claims by affording them some form of preference or privilege over other claims, ${ }^{18}$ or by the increasingly common approach of some form of institution to guarantee workers' claims. ${ }^{19}$ These options are discussed below.

\title{
C Options for Protecting Workers' Claims
}

\section{Privilege or Priority Payment Regimes}

The mechanism of privilege requires amounts owed to employees to receive preferential rights to payment from the assets of the insolvent enterprise before debts owed to other creditors are paid. A 2003 report tabled at the $91^{\text {st }}$ session of the International Labour Conference ('the Report') observed that the preferential treatment of wage claims is by far the most widely accepted and most traditional method of protecting service-related claims in the event of the employer's bankruptcy or the judicial liquidation of an enterprise. ${ }^{20}$ The Report noted that the preference system was first codified in the civil codes of the $19^{\text {th }}$ century, beginning with the Napoleonic Code, initially to protect the wages of domestic servants. Protection was

\footnotetext{
15 UNCITRAL, Legislative Guide on Insolvency Law (Report, 2005) 270 $<$ https://uncitral.un.org/en/texts/insolvency $>$.

16 Ibid 272.

${ }^{17}$ ILO, Protection of Wages Convention, 1949 (No. 95), opened for signature 8 June 1949, C095 (entered into force 24 September 1952) ('C 95').

18 ILO, Protection of Workers' Claims (Employer's Insolvency) Convention of 1992 (No. 173), opened for signature 3 June 1992, C173 (entered into force 8 June 1995) pt II arts 5-8 ('C 173').

${ }^{19}$ Ibid pt III arts 9-13.

${ }^{20}$ General Survey (n 10) [298]-[353].
} 
progressively extended to other categories of wage earners and the preference principle soon gained recognition in both commercial and labour legislation. ${ }^{21}$

However, the Report noted that in most countries unpaid wages are not the only form of debt recognised by law as having a preferential or privileged right to payment. Other claims commonly include the costs of the insolvency proceedings, sums owed to the government for unpaid taxes, or compulsory insurance contributions. ${ }^{22}$ Therefore, the relative priority, or rank, that is given to employee debts in relation to other privileged claims, is equally important. Generally, the insolvency practitioner will be required to satisfy the claims of higher-ranking creditors in full before moving to pay lower-ranked creditors.

Article 11 of C 95 provides that the length of the period or the amount of unpaid wages to be privileged is determined by the national laws of ratifying countries. C 173 partially revised $C$ 95 by providing that the period should not be less than three months prior to the insolvency, and that privilege should extend to all holiday pay earned during the year in which the insolvency occurred and include all severance pay due to the worker upon termination of the employment. ${ }^{23}$ It further provides that, while the amount of workers' claims may be prescribed, this amount should not fall below a socially acceptable level. ${ }^{24}$ However, 98 countries have ratified C 95, and only 21 have done the same for $\mathrm{C} 173 .^{25}$

Another issue is the scope of the employment-related claims. The Report noted that some countries have granted privilege to broader claims, such as holiday pay, allowances in respect of other unpaid leave and redundancy claims. ${ }^{26}$ Also, there are differences between nations in the length of the period prior to the insolvency event for which an employee is able to claim and the total amount that any one employee may claim as a preference debt.

\section{State Guarantees}

A number of jurisdictions have established additional governmental schemes to bolster the protection for unpaid employee claims. Although there are differences between the operation of the different national schemes, essentially the schemes operate as a legislative safety net that pays out to the employee all, or some, of the unpaid amounts due to an employee in the event that there are insufficient funds left within the company to meet these claims. ${ }^{27}$ These schemes generally operate alongside a privilege regime, allowing employees to be promptly paid their preferential claims by the scheme. The schemes are then usually subrogated to the position of

\footnotetext{
${ }^{21}$ In France, the privilege granted to domestic servants was extended in 1838 to cover the claims of wage earners and apprentices for up to six months' wages. Wage claims, however, were placed in the fourth rank of privileged claims and therefore the protection was largely illusory.

${ }^{22}$ In the case of personal bankruptcy, the debtor's personal claims (eg, funeral or medical expenses) and the maintenance claims of the debtor's family members are often also included.

${ }^{23} \mathrm{C} 173$ (n 18) pt II art 6.

${ }^{24}$ Ibid art 7.

25 'Ratification by Convention', International Labour Organization (Web Page, 1996-2017) $<$ https://www.ilo.org/dyn/normlex/en/f?p=1000:12001>.

${ }^{26}$ General Survey (n 10) [306]-[309].

27 Janis Sarra, Employee and Pension Claims during Company Insolvency: A Comparative Study of 62 Jurisdictions (Thomson Canada, 2008).
} 
the employee if, and when, the liquidator or other administrator is able to make any preferential distributions.

\section{Other Options}

Some countries have adopted measures to protect employee entitlements by providing that unpaid amounts due to employees are paid a capped amount before other creditors, including secured creditors. Such measures, known as super priority regimes, recognise the special public policy considerations regarding employee protection. Sarra, in a 2008 comparative study of 62 jurisdictions, ${ }^{28}$ found $40 \%$ of the countries in the study granted a capped super priority for wages and related claims over both secured and unsecured assets. ${ }^{29}$ These included Brazil, Chile, Colombia and Mexico. She found that another $19 \%$ of the jurisdictions granted a partial priority over secured claims, usually over floating charges over personal property, but not including securities over real property. ${ }^{30}$ As discussed below, the exception in New Zealand law for general security interests over accounts receivable and inventory from the claims of the secured creditor is an example of a partial super priority afforded to wage claims over those of a secured creditor. Sarra observed that it is arguable that ranking employee claims before that of secured creditors creates some incentives for such lenders to monitor the debtor company's conformity with its wage and other obligations to employees. ${ }^{31}$

\section{EMPloyeE WAGE Protection IN NeW ZEALAND}

\section{A Statutory Privilege or Preference?}

Against this background, the New Zealand position can be considered. Although New Zealand has not ratified $\mathrm{C} 173$, employees have for many years been assigned preferential creditor status. The current rules are contained in the Companies Act sch 7. If a company goes into liquidation, a liquidator (or the Official Assignee, in the event the company has no assets) will be appointed by either the High Court or by a special resolution of shareholders. ${ }^{32}$ Section 212 of the Companies Act directs the liquidator to pay the preferential claims in the order of priority as set out in sch 7 before the claims of unsecured creditors. Preferential claims are paid by the liquidator primarily from the unencumbered assets of the insolvent company. Secured creditors are free to realise their respective secured collateral, ${ }^{33}$ without regard for the claims by preferential creditors, with one exception. This exception applies only when the assets of the company available for payment of the preferential claims are insufficient to meet the full amount of the claims. In this case, the preferential debts have priority over the claims of any

\footnotetext{
28 Ibid.

${ }^{29}$ Ibid $15-16$

30 Ibid.

31 Ibid 9.

${ }^{32}$ Companies Act s 241(2)(a), (2)(c). Note a liquidator under s 241(2)(b) can also be appointed by a board of directors on the occurrence of an event specified by the constitution of the company.

${ }^{33}$ Ibid s 248(2), which provides that the commencement of the liquidation of a company does not affect the rights of a secured creditor, subject to s 305 of the Act.
} 
person under a security interest to the extent that the security interest is over all, or any part, of the company's accounts receivable and inventory or any part of either of them. ${ }^{34}$

Employee claims are not the first-ranked preferential debts, as a liquidator is required to pay all the claims set out in sch $7 \mathrm{cl} 1$ before making any distribution to employees. The first-ranked debts include all the costs related to the administration of the liquidation, including costs of any previous administration, costs of any creditor who applied to liquidate the company or spent funds protecting the assets of the company. At this level, any employee who continued to work for the company during the liquidation or was engaged by the liquidator would be paid any wages due to that employee as a cost of the liquidation. ${ }^{35}$

After all the first-level debts are paid, a liquidator, providing there are funds available, will pay all employee claims. If there are insufficient funds available, the claims are paid on a pari passu basis. Employees may include claims for unpaid wages and salaries, ${ }^{36}$ untransferred payroll donations, holiday pay, redundancy, reimbursement for lost wages, claims in respect of outstanding deductions for certain employee obligations and employee KiwiSaver obligations. ${ }^{37}$ Unpaid wages and salary are restricted to services rendered to the insolvent employer during the four months preceding the commencement of the formal insolvency. ${ }^{38}$

There is, however, a maximum amount that each employee is entitled to claim, an amount that is adjusted for inflation every three years. ${ }^{39}$ At the time of writing, this amount is NZD23,960. An employee who is owed more than this cap is entitled to claim as an unsecured creditor for the balance. However, as unpaid amounts owed to the Crown for goods and services tax, income tax (PAYE), residents' withholding tax and non-residents' withholding tax are also preferential creditors, albeit ranking after employee claims, non-preferential unsecured creditors' claims often receive very little or nothing. The final restriction is that an 'employee' is given a restrictive definition for the purposes of sch 7. Any person who is or was at any time during the 12 months before the commencement of the liquidation a director or a nominee or relative of a director of the company is excluded from being an employee for the purposes of $\operatorname{sch} 7 .{ }^{40}$

\section{B Comparison with the United Kingdom and Australia}

There is no government institutional guarantee or insurance system in New Zealand. This can be compared to the position in a number of other comparable jurisdictions. For example, in the United Kingdom, the Insolvency Act 1986 (UK) sch 6 lists wages and salaries of employees

\footnotetext{
${ }^{34}$ Ibid sch $7 \mathrm{cl} 2(1)(b)$. The carve out does not include if the security interest is a perfected purchase money security interest or other specific forms of security interests.

${ }^{35}$ Ibid sch $7 \mathrm{cl}$ 1(1)(a), as an expense properly incurred by the liquidator in carrying out the duties and exercising the powers of the liquidator.

${ }^{36}$ This is specifically provided to include unpaid wages and salary, whether or not earned wholly or in part by way of commission and whether payable for time or for piece work.

${ }^{37}$ Companies Act $\mathrm{sch} 7 \mathrm{cl}$ 1(2).

${ }^{38}$ Ibid sch 7 cl 1(2)(a).

${ }^{39}$ Ibid sch $7 \mathrm{cl} 3(2)$.

${ }^{40}$ Ibid sch 7 cl 3(4)(b).
} 
and earning-related social security contributions as having preferential status. Specifically, employees are entitled to claim unpaid wages and holiday pay accruing in the four months prior to a maximum of $£ 800$. However, UK employees are entitled to claim against the state National Insurance Fund ('NIF') by virtue of the Employment Rights Act 1996 (UK). ${ }^{41}$ This Act provides that employees are entitled to claim for unpaid wages (up to eight weeks to a maximum of $£ 479$ per week), notice pay, holiday pay, a basic compensation award for unfair dismissal, any statutory redundancy pay and certain other payments. Once the employee is paid by the NIF, the NIF is subrogated to the rights of the employee as a creditor against the employer, including any rights as a preferential creditor.

Similarly, in Australia, in terms of corporate employers, the Corporations Act 2001 (Cth $)^{42}$ provides that unpaid wages, ${ }^{43}$ superannuation contributions, superannuation guarantee charge, amounts due in respect of injury compensation, amounts related to a leave of absence and retrenchment payments owed to employees are preferential debts. ${ }^{44}$ These claims may only be paid after the costs relating to the liquidation and any prior administration are paid. However, in 2000, the Australian government introduced a nationally funded scheme as a safety net for employees. The scheme was known from 2001 onwards as the General Employee Entitlements and Redundancy Scheme ('GEERS'). ${ }^{45}$ GEERS was replaced by a scheme operated under the Fair Entitlements Guarantee Act 2012 (Cth) ('FEG') in December 2012. FEG allows for employees to claim up to 13 weeks of unpaid wages, unpaid annual leave and long service leave, up to five weeks' payment in lieu of notice, and redundancy pay of up to four weeks per full year of service. To be eligible, the employee must have lost their job due to the employer's liquidation or bankruptcy and be owed one of the entitlements received above, and the insolvency practitioner must confirm that the employee will not be paid this claim, all or in part, as a preferential creditor. As stated above, FEG pays to employees a certain level of unpaid entitlements and the government then becomes a preferential creditor entitled to receive dividend payments in the liquidation. ${ }^{46}$

\footnotetext{
${ }^{41}$ Employment Rights Act 1996 (UK) ss 166-70, 182-90.

${ }^{42}$ Corporations Act 2001 (Cth) s 556 (1)(e)-(g) ('Corporations Act').

${ }^{43}$ Ibid s 9 defines wages in relation to a company as amounts payable to or in respect of an employee of the company (whether the employee is remunerated by salary, wages, commission or otherwise) under an industrial instrument, including amounts payable by way of allowance or reimbursement but excluding amounts payable in respect of leave of absence.

${ }^{44}$ Any employee who falls within the definition of excluded employee in s 556(2) of the Corporations Act may only claim the sum of AUD2,000 in respect of days that are classified as non-priority days. An excluded employee is a person who was a director at any time during the 12 months preceding the liquidation, an employee who is a spouse or relative of a director or former director.

45 The scheme was initially known as the Employee Entitlements Support Scheme and provided for capped payments that guaranteed entitled employees up to 29 weeks of pay at ordinary time's rates. This consisted of a maximum of 4 weeks' unpaid wages, 4 weeks' annual leave, 12 weeks' annual service leave, 5 weeks' pay in lieu of notice and 4 weeks' redundancy payments, and applied to employees whose employment was terminated by reason of employer insolvency after 1 January 2000.

${ }^{46}$ Michael Murray and Jason Harris, Keay's Insolvency, Personal and Corporate Law and Practice (Thomson Reuters, $\left.10^{\text {th }} \mathrm{ed}, 2018\right)$ [15.415] also notes that the Australian government may otherwise exercise its rights as a creditor once it has been subrogated by payment to employees.
} 


\section{Reckless Trading Actions and Other Claims}

In addition to the preference rules, the Companies Act contains other provisions that are available to a liquidator to swell the pot of money available to meet the claims of all creditors, including the claims of preferential creditors. The main group of provisions are the general duties that directors owe to the company, including the duty of care and the duty of good faith. ${ }^{47}$ In addition, the duty against reckless duty and the duty to not incur unperformable obligations are also general duties owed to the company, which as general duties apply to directors at all times - although breach of these duties is likely to occur when a company is struggling financially.

The duty against reckless trading is breached if a director allowed, caused or agreed to the business of the company being operated in such a manner that it was likely to cause serious loss to the company's creditors. ${ }^{48}$ The duty against incurring unperformable obligations imposes a duty on directors to not incur an obligation unless the director objectively believes that at the time the obligation is entered into the company will be able to perform it. ${ }^{49}$ Although, in theory, the board can bring an action at any time against a director for breach of these duties, the reality is that it is liquidators of insolvent companies that initiate most actions before New Zealand courts for breaches. However, these general duties are not automatically breached if a company is unable to pay its creditors, including its employees. Furthermore, it is not a breach of the general duties by themselves to fail to make reasonable provision for unpaid wages, leave entitlements and severance payments in the event of insolvency. Although, clearly, if the company has been allowed to continue to trade when insolvent, effectively operating on capital supplied by its creditors, then a liquidator may wish to consider bringing an action against the directors for compensation.

The Companies Act was amended in 2014 by the introduction of a criminal offence in s 380(4) with respect to dishonestly incurring a debt. A person convicted of an offence under this provision is liable for a term not exceeding five years, or a fine not exceeding NZD200,000. ${ }^{50}$ For a director to have committed an offence, not only must the company have incurred a debt, but the company must have been insolvent at the time or become insolvent because of it, and the director must have known of the company's insolvency whereby the director's failure to prevent the company incurring the debt was dishonest. To date, there have been no prosecutions under the section, which is not surprising given the very high evidential difficulties. The Registrar of Companies ('Registrar') must prove both that a director had the requisite knowledge of the company's insolvency and that the director's failure to act was dishonest.

Therefore, in New Zealand it is not a government agency but rather private sector insolvency practitioners who are largely responsible for enforcement actions against directors and other former controllers of a failed company. If a liquidator does elect to pursue directors or

\footnotetext{
${ }^{47}$ Companies Act ss 131, 137.

48 Ibid s 135.

49 Ibid s 136.

${ }^{50}$ Ibid s 373(4).
} 
controllers for breaches of duties owed to the company, the liquidator may apply to the court for various orders. The principal remedy is set out in s 301 of the Companies Act, and provides that the court may order, on the application of a liquidator, creditor or shareholder, that the person in default must repay or restore the money or property of the company, or contribute such sums to the assets of the company by way of compensation as the court thinks just. ${ }^{51}$ If the court agrees, the standard approach to quantifying the personal liability of a director, as outlined by the Court of Appeal in Mason v Lewis, ${ }^{52}$ is for the court to estimate how much the debts of the company increased from the corporate governance breach date to the date the company is placed in liquidation. Once, this amount is estimated, the court considers three factors: duration, overall culpability and the connection of the debt to the decision to continue trading in establishing the actual quantum. ${ }^{53}$ However, in a recent case, the High Court in Mainzeal Property and Construction Ltd (in liq) $v \mathrm{Yan}^{54}$ took an alternative approach, starting at the total loss to creditors before applying a number of discounts in establishing the quantum. $^{55}$

As noted above, s 301 of the Companies Act contemplates that actions may be brought by a creditor or shareholder, as well as the liquidator. At least in theory, an employee could instigate a claim under the provision. In the case of an application under s 301(1)(c) by a creditor, the courts may order the director to pay, transfer money or property for which the director has misapplied or become liable or accountable direct to the creditor. It should be noted, however, that under New Zealand law directors do not owe any direct duty to creditors by reason of their position as directors of the company. ${ }^{56}$

The vast majority of s 301 applications are initiated by liquidators and there have been a number of very large awards against directors in the past. ${ }^{57}$ But reliance on civil claims by liquidators to bring directors to account is problematic on a number of grounds. First, it depends upon the liquidator having access to sufficient funding, either from company assets or outside funding, to initiate the action against the directors or former directors. Second, as the 2017 Insolvency Working Group observed, the current regime may deter liquidators from bringing a reckless trading claim, as there may be a mismatch between who pays the cost of making the claim and who benefits. ${ }^{58}$ Specifically, while the costs may be met from the remaining assets of the

\footnotetext{
${ }^{51}$ Ibid s 301(1)(b)(i)(ii).

${ }^{52}$ Mason v Lewis [2006] 3 NZLR 225, [109], [120].

${ }^{53}$ Ibid; Lewis v Mason (2009) 10 NZCLC 264, 545, [60]. See also Condrens Parking Ltd (in rec and liq) Re; Jordan v O’Sullivan CIV-2004-485-002611, 13 May 2008 [70]; Goatlands Ltd (in liq) v Borrell (2007) 23 NZTC 21,107, [121]-[133].

${ }^{54}$ Mainzeal Property and Construction Ltd $v$ Yan [2019] NZHC 255.

${ }^{55}$ Ibid [379]-[461].

${ }^{56}$ Kings Wharf Coldstore Ltd (in rec and liq) v Wilson (2005) 2 NZCCLR 1042 [101]-[103].

${ }^{57}$ See, for example, Löwer v Traveller [2006] 3 NZLR 225 where the Court of Appeal at [91] upheld an order of NZD8.4 million against Löwer made by the High Court in South Pacific Shipping Ltd (in liq); Traveller v Löwer (2004) 9 NZCLC 263, 570. Also, see Mainzeal Property and Construction Ltd $v$ Yan [2019] NZHC 255 [445] where an order of NZD36 million was awarded against the directors. At the time of writing, this decision is under appeal.

58 The Insolvency Working Group was a panel of experts appointed in November 2015 by the Ministry of Business, Innovation and Employment to examine and advise on aspects of corporate insolvency law.
} 
company, and therefore indirectly from the amounts available to distribute to the unsecured creditors, a secured creditor who has a security over all of the company's assets will obtain benefits from a successful claim. In some cases, it is the directors who hold the secured debt, thereby rendering any misfeasance action against them to be redundant. ${ }^{59}$

Third, it relies on the professionalism and independence of the liquidator to investigate the actions of those formerly in control of the insolvent business. Historically in New Zealand, there has been a very low bar for who can be appointed as an insolvency practitioner. This has made it relatively easy for shareholders or directors to appoint a director-friendly liquidator who may not be inclined to investigate whether the pre-liquidation activities of the directors breached any of the duties owed to the company. ${ }^{60}$ However, in 2020, a new co-licensing regime for insolvency practitioners will come into force that will require that only licensed liquidators are appointed to be liquidators of insolvent companies. In addition to a relevant tertiary qualification, licensed practitioners must be a member of a licensing body, such as the Chartered Accountants Australia and New Zealand, and are therefore subject to the code of ethics of that body. There are also enhanced independence rules for any liquidator accepting appointment. ${ }^{61}$

Another provision in the Companies Act that may result in a liquidator having more unencumbered funds available to meet employee claims are the voidable transaction provisions in ss 292 and 293, and the provisions that may allow a liquidator to recover company property or equivalent value when there have been transactions at undervalue within certain specified time limits before the commencement of the liquidation. Also, when certain amendments to the Companies $A c t^{62}$ come into force in $2020,{ }^{63}$ there will be an additional clawback regime for any transactions between the date of filing for the appointment of a liquidator and appointment.

In terms of the powers of the Registrar to act against directors, the Registrar, together with the Financial Markets Authority ('FMA'), does have a power to prohibit any person from being a director of a company, or being concerned in the management of a company. The person must have been involved in the previous five years in the management of a company that had been put into liquidation or ceased to carry on business because of its inability to pay its debts as

\footnotetext{
${ }^{59}$ Insolvency Working Group, Ministry of Business, Innovation and Employment, New Zealand Government, Review of Corporate Insolvency Law: Report No. 2 of the Insolvency Working Group, on Voidable Transactions, Ponzi Schemes and Other Corporate Insolvency Matters (Report No 2, 15 May 2017) 47. See also Office of the Minister of Commerce and Consumer Affairs, New Zealand Government, Insolvency Law Reform (Cabinet Paper, 4 November 2019) [39] <https://www.mbie.govt.nz/assets/insolvency-law-reform.pdf>, which recorded Cabinet's approval to amend the Companies Act by restricting reckless trading recoveries to unsecured creditors. ${ }^{60}$ Insolvency Working Group, Ministry of Business, Innovation and Employment, New Zealand Government, Review of Corporate Insolvency Law: Report No. 1 of the Insolvency Working Group, on Insolvency Practitioner Regulation and Voluntary Liquidations (Report No 1, 27 July 2016) 31-35.

${ }^{61}$ For an outline of the new regime, see Trish Keeper, 'New Co-Licensing Regime for New Zealand's Corporate Insolvency Practitioners' (2019) 8 Company and Securities Law Bulletin 89.

${ }^{62}$ Insolvency Practitioners Regulation (Amendments) Act 2009 (NZ) s 53 inserts new ss 296A-D into the Companies Act. The commencement date for these new provisions is expected to be mid-2020.

${ }^{63}$ For an explanation of the new voidable disposition regime, see Trish Keeper, 'New Voidable Disposition Regime and Changes to Related Party Voting Roles' (2019) 8 Company and Securities Law Bulletin 93, 93-94.
} 
and when they become due. ${ }^{64}$ This power is additional to the powers of the Registrar, amongst others, to apply to the courts to disqualify a person from being a director if they have been persistently non-compliant with the law, guilty of fraud, in breach of their duty to the company, or acting in a reckless or incompetent manner in the performance of their duties as a director. ${ }^{65}$ There are also a range of offences under the Companies Act that the Registrar or the FMA may use against a malfeasant director, including prohibitions against false statements, ${ }^{66}$ and the narrowly defined phoenix company similar name offence. ${ }^{67}$

\section{DiscUSSION}

It is unclear to what extent employees in New Zealand are not receiving part or all of their preferential claims, as this data is not published ${ }^{68}$ Certainly, reports in the media, especially in respect of corporate failures in the building and hospitality industry, support an assertion that the protection afforded by the existing statutory wage protection provisions is illusory. Often under the more general heading of 'wage theft', examples of corporate failures resulting in employees not receiving their full entitlements are regularly featured in the media ${ }^{69}$ and blogs. ${ }^{70}$

What is clear is that whether specific employees do receive any unpaid wages and other entitlements will depend on a number of factors, including the extent of the employer's debt, to what extent that debt is secured and the amount of the first-ranking claims. Furthermore, the existence of the privilege for wage claims in itself does not guarantee debt recovery. In contrast, the statutory guarantee schemes implemented in Australia and the UK ensure that an employee's entitlements are guaranteed and employees are certain to be paid their entitlements in full (up to the specified statutory limits) even if the liquidator of the former corporate employer has no funds to distribute or if the claims as secured creditors exhaust the insolvent company's estate even before the preferential creditors are paid. In addition, employees are paid without having to wait for the liquidator to realise assets or take the other steps outlined above that may swell the total funds available to distribute to creditors.

Interestingly, in 1999 the New Zealand Law Commission recommended that some form of wage earner protection fund be considered as a means of better securing the protection of

\footnotetext{
${ }^{64}$ Companies Act s 385.

65 Ibid s 383.

${ }^{66}$ Ibid s 377 and offences under the Crimes Act 1961 (NZ).

${ }^{67}$ Companies Act s 368A.

${ }^{68}$ In contrast, Helen Anderson reports that in 2011-13, according to ASIC statistics, Australian employees recovered $75 \%$ of their entitlements under the priority provisions in the Corporations Act. See Anderson (n 2) 7677 , fn 5.

${ }^{69}$ See, for example, Debrin Foxcroft, 'Staff Struggle to Get What They Are Owed from Failed Restaurant Chain Wagamama', Stuff (Web Page, 11 August 2019) < https://www.stuff.co.nz/business/114913504/staff-strugglingto-get-what-they-are-owed-from-failed-restaurant-chain-wagamama>; Debrin Foxcroft, 'Wage Theft Has Become a Business Model in the Hospitality Industry', Stuff (Web Page, 12 August 2019) $<$ https://www.stuff.co.nz/business/opinion-analysis/114853237/wage-theft-has-become-a-business-model-inthe-hospitality-industry>.

70 See, for example, Chloe Ann-King, 'Raise the Bar', Millennialposse (Blog Post, 27 March 2020) $<$ https://millennialposse.wordpress.com $>$.
} 
vulnerable employees at whom priority or privilege is directed. ${ }^{71}$ The fund would be based on employer levies, ${ }^{72}$ and was favoured as it would guarantee payment, reduce the amount of litigation and only require a limited amount of government funding to maintain the fund. However, the recommendation did not find favour with the Ministry of Economic Development ('MED'). In 2001, MED published a discussion document that strongly recommended against the establishment of such a fund. ${ }^{73}$ In MED's view, it would penalise successful firms, create a moral hazard, benefit only some employees and be excessively costly. ${ }^{74}$

There is some merit in these criticisms, as illustrated by the fact that the Australian FEG scheme at the time of writing is being reviewed due to a high incidence of fraud and abuse. Anderson observed that there is some evidence that GEERS (and now the FEG) has acted as a disincentive to directors from providing for the payment of accrued employee entitlements, on the basis that these will be provided for by the government. ${ }^{75}$ She continued that 'economic efficiency requires that the cost of avoiding risk should be borne by the party which can most cheaply estimate it and avoid it', and it is the employer who is the party who understands and controls the risk of loss of employee entitlements and can most cheaply make provision for them, rather than the federal government, which socialises the cost to the taxpayer. Accordingly, she concludes that Australia should enact new regulations to provide incentives for the employer, through the decisions of its directors, to take appropriate care. ${ }^{76}$

In the New Zealand context, amending the Companies Act to impose personal liability on directors for unpaid employee entitlements due to the misconduct of the directors would be problematic. First, as outlined above, the majority of enforcement actions against directors are brought by liquidators. If liquidators are to be expected to also bring actions against directors on behalf of employees, the issue would be who pays for liquidators' costs and fees in pursuing such claims. Second, for enforcement to have an impact on deterring directorial misconduct and inattention to company affairs, then criminal sanctions are likely to be necessary. Only a government agency potentially would have the resources to pursue directors for what often may be comparatively insignificant amounts of money compared to the total debt owed by an insolvent corporate employer. Prosecution by a government agency would rely on liquidators advising the agency of unpaid entitlements, although the exact amount of the underpayment may not be known until the final distribution is made. Prosecution of directors will also not ensure that employees get paid, other than by indirectly creating incentives for directors to take appropriate care.

\footnotetext{
${ }^{71}$ New Zealand Law Commission, New Zealand Government, Priority Debts in the Distribution of Insolvent Estates: An Advisory Report to the Ministry of Commerce (NZLC SP No 2, October 1999) [88]-[89]. Unfortunately, as consideration of such a fund was not within its terms of reference, the Law Commission did not make detailed suggestions as to possible form or structure.

${ }^{72}$ As recommended by the Australian Law Reform Commission, Australian Government, General Insolvency Inquiry (ALRC Report No 45, 1988).

${ }^{73}$ Ministry of Economic Development, New Zealand Government, Insolvency Law Review: Tier One Discussion Documents (Report, January 2001).

${ }^{74}$ New Zealand Law Commission (n 71) [88]-[89].

75 Anderson (n 2) 77, 95.

${ }^{76}$ Ibid 94-95.
} 
The question that has to be answered before any reform is considered is what is the objective of that reform? If it is to protect employees, then some form of government fund would be the solution. If it is to punish miscreant directors, then some form of government enforcement would be required. Although, it should be noted that the New Zealand government has shown little interest in increasing the protection afforded to employee entitlements under the current preferential arrangements in the Companies Act. In fact, the only imminent change to the regime is the announcement by the Minister of Commerce and Consumer Affairs on 4 November 2019 that Cabinet has approved changes to the existing employee payment preference scheme by expanding the list of claims that an employee can claim as a preferential payment. The proposal is to amend the employee entitlements to include long serve leave and payments in lieu of notice. ${ }^{77}$ There is no corresponding proposal to increase the level of the cap, however, which is low by international standards.

At a policy level, it is arguable that priorities based on social concerns should be addressed by laws other than the insolvency law. UNCITRAL notes that using insolvency law to satisfy social objectives that are only indirectly related to questions of debt and insolvency 'may at best afford an incomplete and inadequate remedy for the social problem, while at the same time rendering insolvency proceedings less effective'. ${ }^{78}$ Reforms to protect employees on the insolvency of their employer are arguably best made by labour law academics and unions. Van Eck et al observed, with respect to the introduction of fair labour practices into South African insolvency law, that it was the labour movement and not the needs of insolvency practice that was the engine driving the insolvency law reform processes that have taken place in South Africa. ${ }^{79}$ Moreover, in Australia, although the state guarantee scheme had been operating since 2000, it was taken over by FEG in 2012 as a result of the Gillard Government's promises, prior to the 2010 election, to protect workers' entitlements. Anderson suggests that the new laws were prompted by a combination of core Labor principles, encompassing the protection of workers' rights and calls from trade unions for additional protections. ${ }^{80}$

\section{CONCLUSION}

In those insolvency situations where the business of the employer is not capable of rescue, either through some form of arrangement or compromise with creditors or hiving off the viable parts to another entity, most countries have recognised the necessity of some form of preferential treatment for unpaid employees over other unsecured creditors. ${ }^{81}$ As employees are often unable or ill-prepared to protect their own interests, and employers and other creditors are unlikely to put first the interests of employees, the public interest demands some form of government intervention to provide a degree of protection for employees on the insolvency of

\footnotetext{
${ }^{77}$ Cabinet Minute, New Zealand Government, 'Insolvency Law Reform' (CAB-19-MIN-0491.01, 23 September 2019) 2.

${ }^{78}$ UNCITRAL (n 15) 271.

${ }^{79}$ Stefan Van Eck et al, 'Fair Labour Practices in South African Insolvency Law' (2004) 121 South African Law Journal 902, 906.

80 Anderson (n 2) 86.

81 See Andrew Keay et al, 'Preferential Debts in Corporate Insolvency: A Comparative Study' (2001) 10 International Insolvency Review 167; Cantlie (n 9) 412.
} 
their employer. Although it is difficult to establish the effectiveness of the preferential regime for unpaid entitlements in New Zealand law, there are also difficulties with imposing new obligations on liquidators. Any new measures to protect employees may be best undertaken as part of wider move to ensure that workers in New Zealand receive fair wages and protections. 